University of Rhode Island

DigitalCommons@URI

Open Access Master's Theses

2019

\title{
GLOBAL PATTERNS OF NET RESPIRATION IN SUBSEAFLOOR SEDIMENT
}

Victoria Madison Fulfer

University of Rhode Island, vmf713@uri.edu

Follow this and additional works at: https://digitalcommons.uri.edu/theses

\section{Recommended Citation}

Fulfer, Victoria Madison, "GLOBAL PATTERNS OF NET RESPIRATION IN SUBSEAFLOOR SEDIMENT"

(2019). Open Access Master's Theses. Paper 1734.

https://digitalcommons.uri.edu/theses/1734

This Thesis is brought to you for free and open access by DigitalCommons@URI. It has been accepted for inclusion in Open Access Master's Theses by an authorized administrator of DigitalCommons@URI. For more information, please contact digitalcommons-group@uri.edu. 


\section{GLOBAL PATTERNS OF NET RESPIRATION \\ IN SUBSEAFLOOR SEDIMENT}

BY

VICTORIA MADISON FULFER

\section{A THESIS SUBMITTED IN PARTIAL FULFILLMENT OF THE REQUIREMENTS FOR THE DEGREE OF MASTER OF SCIENCE \\ IN OCEANOGRAPHY}

UNIVERSITY OF RHODE ISLAND 


\section{MASTER OF SCIENCE THESIS}

$\mathrm{OF}$

VICTORIA MADISON FULFER

\section{APPROVED:}

Thesis Committee:

\begin{tabular}{|c|c|}
\hline \multirow[t]{4}{*}{ Major Professor } & Steven D'Hondt \\
\hline & Rebecca Robinson \\
\hline & Thomas Boving \\
\hline & $\begin{array}{l}\text { Nasser H. Zawia } \\
\text { N OF THE GRADUATE SCHOOL }\end{array}$ \\
\hline
\end{tabular}




\begin{abstract}
Microbial life is abundant in subseafloor sediment. Rates of respiration in subseafloor sediment appear to be very slow, but are generally poorly constrained. This thesis aims to address this problem by quantifying respiration rates in subseafloor sediment at sites across the globe and determining geographic patterns of depthintegrated respiration rates and average per-cell respiration rates. First, we compiled pore water profiles and descriptive data from scientific coring and drilling sediment cores deposited in publicly accessible databases. Using these profiles, we quantified the global distribution of net respiration rates in subseafloor sediment $(>1.5$ meters below seafloor) using (i) a reaction-transport algorithm, (ii) sediment physical properties, and dissolved oxygen, sulfate, and inorganic carbon concentration data from interstitial waters of sediment cores, and (iii) correlations of net respiration rates to sedimentation rate and sea-surface chlorophyll- $a$ concentration.

Our results indicate depth-integrated net global respiration in subseafloor sediment to be $2.6 \times 10^{12} \pm 0.25 \times 10^{12} \mathrm{~mol} \mathrm{e} / \mathrm{yr}$. Comparison to the global rate of organic-matter burial in marine sediment indicates that most organic matter in subseafloor sediment ( $>1.5 \mathrm{mbsf})$ goes unconsumed. Respiration rates per unit area vary between abyssal regions, where aerobic respiration dominates and rates are lowest, and continental margin regions, where anaerobic respiration dominates and rates are generally higher. Regional areal net respiration can vary by as much as six orders of magnitude. Mean per-cell respiration rates are much slower in subseafloor sediment than in the ocean, although both environments have equivalent numbers of prokaryotic cells. Per-cell respiration rates in subseafloor sediment are generally
\end{abstract}


higher in regions dominated by aerobic respiration than in regions of anaerobic respiration. When combined with a recent estimate of radiolytic chemical production in subseafloor sediment, the potential total respiration rate in the sediment increases to $1.3 \times 10^{13} \mathrm{~mol} \mathrm{e} / \mathrm{yr}$, but is 10,000 times lower than the electron-equivalent rate of carbon fixation in the ocean. This work contributes to the growing collection of studies showing cells in subseafloor sediment live at rates much slower than those seen in the ocean and surface world. 


\section{ACKNOWLEDGMENTS}

First and foremost, I would like to extend my sincerest thanks to my advisor Steve D'Hondt for his guidance throughout this project and for his mentorship and dedication to my development as a scientist. I would also like to thank my committee members Becky Robinson and Tom Boving for their thoughts, suggestions, and guidance throughout this process. I would like to extend special thanks to Rob Pockalny, who, together with Steve, launched my career in the oceanographic sciences and introduced me to what this career path could hold. I would also like to thank Rob for his dedication in teaching me how to complete many facets of this project, from the modeling intricacies to the coding languages we used. Thank you to Art Spivack for taking the time to teach an individual course so that I could better understand the theory and math behind my work. To Justine Sauvage, Ashton Flinders, and Jens Kallmeyer, thank you for providing me with critical data.

To the "D'Hondt lab" members, current and former, thank you for your support, advice, and camaraderie. Special thanks to Zak Kerrigan for being there from beginning to end and for the many laughs. I would like to thank David Smith, Dennis Graham, and Meredith Clark for their support all these years. I would like to thank all of my friends for their advice, encouragement, and for the fun times that falls between all the work. I would like to extend special thanks to Kelsey James, Colin Jones, Loes van Dam, Jacob Strock, and Victoria Treadaway; I could not have done this without you. Thank you to the dream girls, Megan Mullis, Mary Sabuda, and Carrie Harris for keeping me sane and supporting me from all over the country. 
Thank you to Bosun and Maverick for being there 24/7. Thank you to my sisters, Kayla, Jayne, and Tessa, for being lifelong mentors and friends, and for being there no matter what. Lastly, and most importantly, thank you to my wonderful parents, Kathleen and Larry Fulfer, for supporting and loving me and always teaching me to follow my dreams and never give up. 


\section{PREFACE}

This thesis is written in the manuscript format specified by the University of Rhode Island Graduate School.

Manuscript I is written for the Proceedings of the National Academy of Sciences (PNAS) and will be submitted for review upon completion of this thesis. 


\section{TABLE OF CONTENTS}

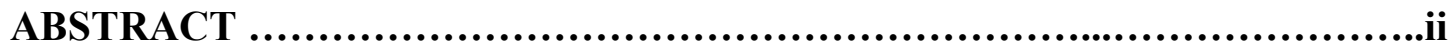

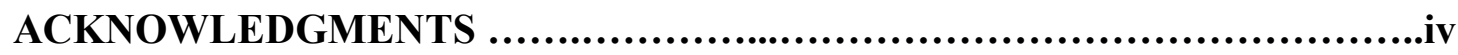

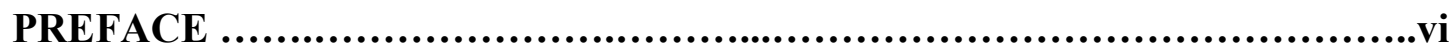

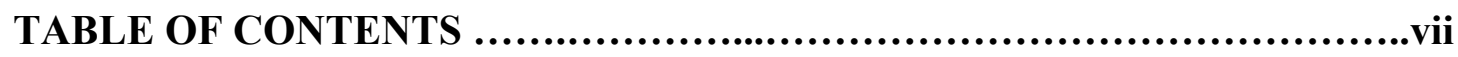

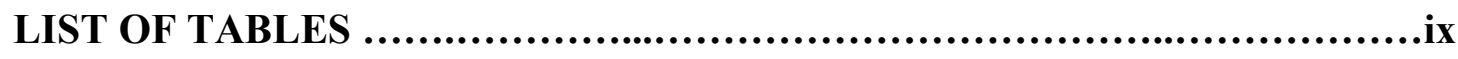

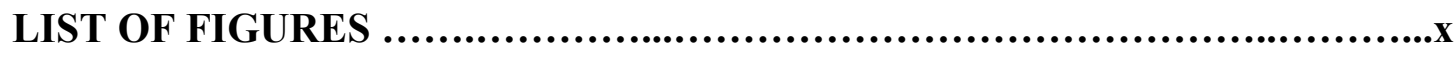

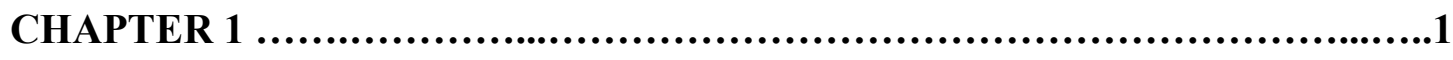

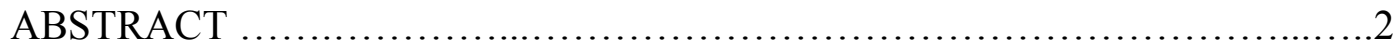

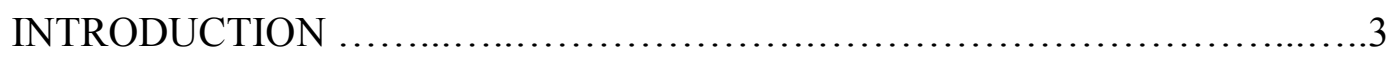

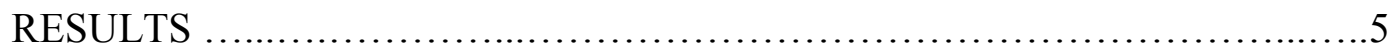

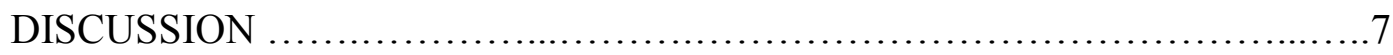

MATERIALS AND METHODS ................................................11

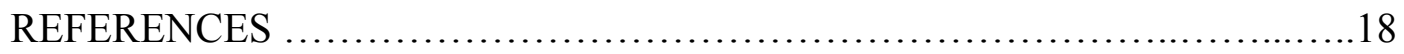

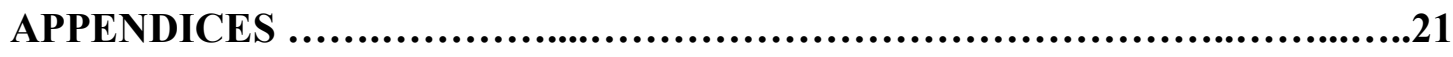

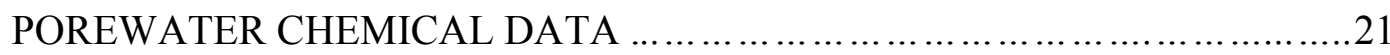

QA/QC OF DISSOLVED CHEMICAL MEASUREMENTS _.......................21

GLOBAL GRIDS OF ENVIRONMENTAL PARAMETERS .......................21

CREATION OF THE SEDIMENTATION RATE GRID ….......................22

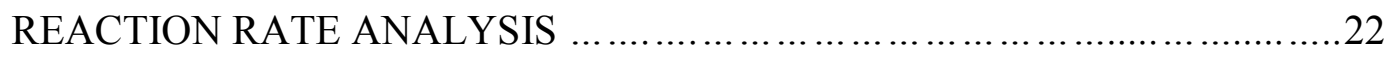

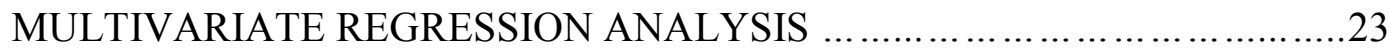

CREATION OF THE GLOBAL MODEL ......................................25 
MODEL MODIFICATIONS FOR COMPARISON TO GLOBAL CELL ABUNDANCE AND RADIOLYTIC CHEMICAL PRODUCTION .............26

CALCULATION OF PER-CELL RATES ...............................26

COMPARISON TO DIC PRODUCTION RATES ............................27

COMPARISON TO A PREVIOUS ESTIMATE OF GLOBAL DISTRIBUTIONS

$\mathrm{OF} \mathrm{SO}_{4}{ }^{2-}$ AND $\mathrm{O}_{2}$ REDUCTION IN SUBSEAFLOOR SEDIMENT .... .28

COMPARISON TO GLOBAL PATTERNS OF RADIOLYTIC $\mathrm{H}_{2}$

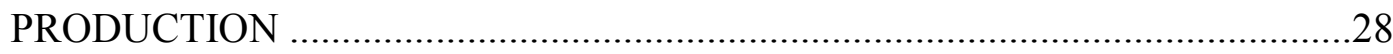

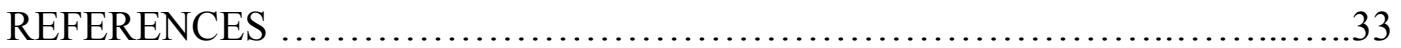




\section{LIST OF TABLES}

TABLE

PAGE

Table 1. Coefficients of determination $\left(\mathrm{R}^{2}\right)$ for variables used in a multiparametric backstepping regression analysis. Best fit equation parameters for chosen variables. 


\section{LIST OF FIGURES}

FIGURE

PAGE

Figure 1. Global distribution of subseafloor sedimentary respiration rate ( $\left.\mathrm{mol} \mathrm{e}-/ \mathrm{m}^{2} / \mathrm{yr}\right)$

(A). Background colors on all plots represent modeled respiration rates denoted by the color bar. Dot colors indicate calculated respiration rates for individual sites (based on dissolved chemical measurements and sediment properties). Dots of the two darkest blues are where aerobic respiration occurs. Within the black contour line is where aerobic respiration is predicted to occur, and outside of the black contour is where anaerobic respiration is predicted to occur (A). Model residuals are normally distributed beneath the purple normal distribution curve, calculated from the standard deviation (B). The model is based on sedimentation rate and sea surface chlorophyll-a for both shallow $(<2000 \mathrm{~m})(\mathrm{C})$ and abyssal $(>2000 \mathrm{~m})(\mathrm{D})$ regions. $50 \%$ of the naturally occurring sedimentation rate and chlorophyll- $a$ fall within the red contour $(\mathrm{C}$ and D). Gray regions denote combinations of chlorophyll-a and sedimentation rate that are not naturally occurring $(\mathrm{C}$ and $\mathrm{D})$. 14 Figure 2. Global distribution of mean per-cell respiration rates below $1.5 \mathrm{mbsf}\left(\mathrm{mol} \mathrm{e}^{-}\right.$ /cell/yr) (B and D) calculated from the global distribution of cell abundance below 1.5 mbsf, modified from Kallmeyer et al. (2012) and the global distribution of net respiration rates below $1.5 \mathrm{mbsf}(\mathrm{A})$ or potential total respiration (net respiration plus potential radiolysis-fueled respiration) rates below $1.5 \mathrm{mbsf}(\mathrm{C})$. 16

Figure 3 . The relative difference between globally predicted radiolytic hydrogen production (Sauvage, 2018) and net respiration in subseafloor sediment. Net 
respiration exceeds hydrogen production in blue regions. Red and regions denote where radiolytic hydrogen production most and least outweigh respiration, respectively.

Supplemental Figure 1. The locations of sites used in this study. Circles represent sites with down-core dissolved oxygen concentration measurements and trace sulfate concentrations. Triangles represent sites with down-core dissolved sulfate concentration measurements. Colored symbols identify sites included in the final model for sulfate (red) and oxygen (blue). Yellow and green regions denote the shallow $(<2000 \mathrm{~m})$ and abyssal $(>2000 \mathrm{~m})$ regions respectively 29 Supplemental Figure 2. Profiles of net respiration rates in sediment. (A) Profile of net $\mathrm{O}_{2}$ reduction (aerobic respiration) rate as a function of sediment depth at site KN22303. The crosshatched region represents the depth of igneous basement. Inset shows the same profile with an adjusted vertical scale. (B) Profile of net $\mathrm{SO}_{4}{ }^{2-}$ reduction (anaerobic respiration) rate as a function of sediment depth at ODP Site 981. (C) Profile of net $\mathrm{SO}_{4}{ }^{2-}$ reduction rate as a function of sediment depth at ODP Site 1063, where dissolved $\mathrm{SO}_{4}{ }^{2-}$ disappears at a shallow sediment depth. Circles indicate measured $\mathrm{O}_{2}$ or $\mathrm{SO}_{4}{ }^{2-}$ concentrations. Red lines indicate net respiration rates. Gray shaded regions represent uncertainty (one standard deviation) in the respiration rate. 
Supplemental Figure 3. The relationship between DIC production rates and sulfate reduction rates at 9 sites. The black line represents a linear best fit with a slope of

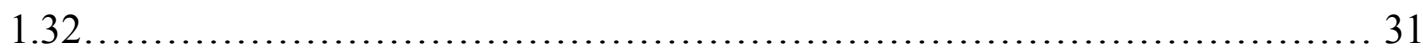

$\begin{array}{lll}\text { Figure } & \text { Page }\end{array}$

Supplemental Figure 4. Global distribution of subseafloor sedimentary respiration rate ( $\mathrm{mol} \mathrm{e} \mathrm{e}^{-/} \mathrm{m}^{2} / \mathrm{yr}$ ). Within the black contour line is where aerobic respiration is predicted to occur. Anaerobic respiration is predicted to occur at all locations outside of the contour (A) Global distribution of dissolved oxygen and sulfate in subseafloor sediment. Oxygen reduction is expected to dominate in blue regions, while sulfate reduction is expected to dominate in white and yellow regions $(\mathbf{B})$. A direct comparison between areas of predicted aerobic and anaerobic respiration in subseafloor sediment, with both models predicting aerobic respiration in orange regions and anaerobic respiration in blue regions. The two models have conflicting

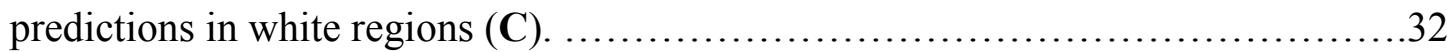




\section{MANUSCRIPT - I}

To be submitted to the Proceedings of the National Academy of Sciences, December 2019

\section{Global Patterns of Net Respiration in Subseafloor Sediment}

Victoria M. Fulfer, Robert Pockalny, and Steven L. D’Hondt

Graduate School of Oceanography, University of Rhode Island, Kingston, RI, USA

Corresponding Author: Victoria M. Fulfer

Graduate School of Oceanography

University of Rhode Island

215 South Ferry Rd.

Narragansett, RI, 02882, USA

Email address: vmf713@uri.edu 


\section{ABSTRACT}

We have compiled and analyzed decades of published scientific coring and drilling data to quantify the global distribution of net respiration in subseafloor sediment. Net respiration per unit area varies from site to site by as much as six orders of magnitude. Based on correlations to sedimentation rate and sea surface chlorophyll$a$, we estimate depth-integrated net global respiration in subseafloor sediment to be $2.6^{*} 10^{12} \mathrm{~mol} \mathrm{e}-/ y r$. In abyssal regions, aerobic respiration dominates and net respiration rates are lowest. Near continental margin regions, anaerobic respiration dominates and rates are generally higher. Anaerobic activity dominates subseafloor sedimentary respiration in up to $65 \%$ of the global ocean area, but contributes $94 \%$ of the global net respiration in subseafloor sediment. Although total cell number in marine sediment is comparable to total cell number in the ocean (Kallmeyer et al., 2012), mean per-cell respiration rates are much slower in subseafloor sediment than in the ocean. Mean per-cell rates in subseafloor sediment are generally higher in regions dominated by aerobic respiration than in regions dominated by anaerobic respiration. When a recent estimate of radiolytic chemical (electron donor and electron acceptor) production in subseafloor sediment (Sauvage, 2018) is considered, total respiration in subseafloor sediment may be as high as $1.3^{*} 10^{13} \mathrm{~mol} \mathrm{e} / \mathrm{yr}-\mathrm{a}$ factor of five higher than the global net (organic-fueled) respiration rate. Even with this potential increase, the global respiration rate of subseafloor sedimentary life is 10,000 times slower than the global rate of photosynthetic carbon fixation in the ocean (Behrenfeld and Falkowski, 1997). 


\section{INTRODUCTION}

Bacteria and archaea are abundant (ca. $2.9 * 10^{29}$ cells globally) (1) and active $(2,3)$ in marine sediment, but per-cell respiration rates in subseafloor sediment are extremely low (4-6). Based on estimates of net respiration, microbes in subseafloor sediment catabolize $10^{4}$ to $10^{6}$ times more slowly than microbes in pure culture (4), with biomass turnover times of hundreds to thousands of years (3). The slow growth rates are limited by low bioavailable energy fluxes in the subseafloor $(4,6-10)$.

The past five decades of scientific ocean drilling and coring expeditions have generated chemical, biological, physical, and geological data for subseafloor sediment at hundreds of sites across the globe. Analyses of these data have greatly increased understanding of subseafloor life (e.g., ref. 4-8, 11, 12) and contributed to major advances in climatic and oceanographic sciences $(13,14)$. In oxic marine sediment, oxygen $\left(\mathrm{O}_{2}\right)$ is the predominant electron acceptor used to oxidize organic matter $(4,7)$, while in anoxic marine sediment, sulfate $\left(\mathrm{SO}_{4}{ }^{2-}\right)$ is the predominant external electron acceptor $(4,7,15-17)$. Therefore, depth-integrated rates of $\mathrm{SO}_{4}{ }^{2-}$ and $\mathrm{O}_{2}$ reduction are direct measures of anaerobic and aerobic net respiration in subseafloor sediment (4, 11, 17). Dissolved inorganic carbon $\left(\mathrm{DIC}=\mathrm{CO}_{2}+\mathrm{HCO}_{3}{ }^{-}+\mathrm{CO}_{3}{ }^{2-}\right)$ is the primary product of net respiration in subseafloor sediment (4). At sites where $\mathrm{SO}_{4}{ }^{2-}$ is completely reduced within the sediment, DIC is utilized as an electron acceptor at greater depths, where other net electron acceptors are rare (8).

Several previous studies have used chemical concentration data and sediment physical properties to quantify $\mathrm{SO}_{4}{ }^{2-}$ reduction rates or $\mathrm{O}_{2}$ reduction rates at individual 
sites (e.g., ref. 5-7, 11, 18, 19). Such studies have yielded key insights into subseafloor life; for example, they have provided the primary evidence that per-cell respiration rates and per-cell energy fluxes are extraordinarily slow in subseafloor sediment (e.g., ref. 8, 12). Other studies have used chemical concentration data and sediment properties from many sites (alone or in combination with radiotracer measurements of potential activity) to calculate global rates of $\mathrm{SO}_{4}{ }^{2-}$ reduction in marine sediment (e.g., ref. 17, 20). The latter studies placed important bounds on the global sulfur cycle and its relationship to the marine carbon cycle.

Another source of energy in subseafloor sediment are hydrogen $\left(\mathrm{H}_{2}\right)$ and oxidants produced through radiolysis, or the splitting of water $(21,22)$. A recent study showed that radiolysis is a principle source of electron donors and acceptors for microbial communities in subseafloor sediment from the surface down to the depth of basement or $0.1 \%$ sediment porosity (23). It is not yet clear how much subseafloor life could be living off the products of radiolysis.

No previous studies have explicitly focused on the total organic-fueled respiration of subseafloor sedimentary life or on broad patterns of subseafloor organicfueled respiration throughout the entire ocean. Furthermore, no previous studies have quantified the total rate or geographic distribution of subseafloor aerobic respiration, or its contribution to total organic-fueled respiration in subseafloor sediment.

To advance understanding of subseafloor life, this study has the following objectives. The first objective is to quantify how net (organic-fueled) respiration in subseafloor sediment varies from site to site and region to region. The second objective is to quantify the global rate of net respiration by the subseafloor 
sedimentary ecosystem, and place it in the context of other global metabolic rates. The third objective is to quantitatively assess the potential relative dependence of subseafloor sedimentary life on (i) organic oxidation (net respiration) and (ii) radiolytic redox chemicals produced within the same sediment.

\section{RESULTS}

Depth-integrated rates of net $\mathrm{SO}_{4}{ }^{2-}$ reduction (at 63 sites) and net $\mathrm{O}_{2}$ reduction (at 11 sites) were calculated using concentration profiles of dissolved $\mathrm{SO}_{4}{ }^{2-}$ and $\mathrm{O}_{2}$ in subseafloor sediment [sediment deeper than 1.5 meters below seafloor (mbsf)] (Supplemental Figure 2)(19). The environmental factors correlating best with the $\mathrm{SO}_{4}{ }^{2-}$ and $\mathrm{O}_{2}$ reduction rates were determined by comparing reduction rates against global grids of sedimentation rate (24-26), sea surface chlorophyll- $a$ (27), distance

from land (1), water depth (28), and sea-surface temperature (29) in a multiparametric regression analysis (Table 1). Global grids of sedimentation rate (24-26), and sea surface chlorophyll- $a$ (27) correlated best with respiration rates based on their high $\mathrm{R}^{2}$ values. We created a global model of subseafloor microbial respiration for both shallow continental shelf $\left(<2000 \mathrm{~m}\right.$ water depth; $\left.\mathrm{R}^{2}=0.84\right)$ and abyssal $(>2000 \mathrm{~m}$ water depth; $\mathrm{R}^{2}=0.76$ ) regions using the output of this regression analysis (Figure 1)(Table 1).

Net respiration rates are lowest (minimum rate $6.0^{*} 10^{-7} \mathrm{~mol} \mathrm{e} / \mathrm{m}^{2} / \mathrm{yr}$ ) in abyssal regions and highest (maximum rate $5.2^{*} 10^{-1} \mathrm{~mol} \mathrm{e} / \mathrm{m}^{2} / \mathrm{yr}$ ) in continental margin regions and in other areas with high sedimentation rates. Sulfate reduction dominates along continental shelves and at the equator, where net respiration rates are 
high $\left(2.5^{*} 10^{-3}\right.$ to $\left.5.2 * 10^{-1} \mathrm{~mol} \mathrm{e} / \mathrm{m}^{2} / \mathrm{yr}\right)$. Oxygen reduction dominates in the sediment beneath ocean gyres and near mid-ocean ridges, where net respiration rates are low $\left(6.0 * 10^{-7}\right.$ to $2.5^{*} 10^{-3} \mathrm{~mol} \mathrm{e} / \mathrm{m}^{2} / \mathrm{yr}$ ) (Figure 1$)$. Summation of the rates from both regions yields global net respiration in subseafloor $(>1.5 \mathrm{mbsf})$ sediment of $2.6^{*} 10^{12} \pm$ $0.25 * 10^{12} \mathrm{~mol} \mathrm{e} / \mathrm{yr}$. Although the regions of subseafloor sediment dominated by $\mathrm{O}_{2}$ reduction cover about $35 \%$ of the total seafloor, aerobic respiration accounts for only around $6 \%$ of the global net respiration in subseafloor sediment.

Comparison of $\mathrm{SO}_{4}{ }^{2-}$ reaction rates to DIC production rates indicates that net $\mathrm{SO}_{4}{ }^{2-}$ reduction approximates net organic-matter oxidation in anoxic subseafloor sediment. Dissolved $\mathrm{SO}_{4}{ }^{2-}$ data and DIC data allow direct comparison of $\mathrm{SO}_{4}{ }^{2-}$ reduction rates and DIC production rates in the subseafloor sediment of nine sites. For those sites, the mean relationship of $\mathrm{SO}_{4}{ }^{2-}$ reduction rate to DIC production rate is roughly 1-to-1 $(\mathrm{m}=1.3)$ (Supplemental Figure 3$)$. This result reinforces the longstanding recognition that $\mathrm{SO}_{4}{ }^{2-}$ is the dominant electron acceptor for degrading organic matter in anoxic marine sediment $(4,7,15-17,19)$. Comparison of $\mathrm{O}_{2}$ reduction rates to $\mathrm{NO}_{3}{ }^{-}$production rates has similarly shown that net $\mathrm{O}_{2}$ reduction approximates net organic-matter oxidation in oxic subseafloor sediment.

To quantify global patterns of mean respiration per-cell in subseafloor sediment, we calculated mean per-cell respiration rates from (i) our depth-integrated net respiration rates and (ii) the global distribution of depth-integrated cell abundance in subseafloor sediment (extracted from Kallmeyer et al., 2012)(1) (Figure 2B). The average net respiration rate per-cell ranges from $4.2^{*} 10^{-19}$ and $5.8^{*} 10^{-14} \mathrm{~mol} \mathrm{e} / \mathrm{cell} / \mathrm{yr}$. 
Mean per-cell rates are highest in the abyssal ocean, where net respiration is generally aerobic, and lowest near continental margins, where net respiration is anaerobic.

\section{DISCUSSION}

The depth-integrated net global respiration in subseafloor sediment $-2.6 * 10^{12}$ $\pm 0.25 * 10^{12} \mathrm{~mol} \mathrm{e} / \mathrm{yr}-$ is less than $1 \%$ of previous estimates of organic carbon flux to the seafloor $\left[\sim 2^{*} 10^{14} \mathrm{~mol} \mathrm{C} / \mathrm{yr}(30,31)\right.$, equivalent to $\left.\sim 8^{*} 10^{14} \mathrm{~mol} \mathrm{e}-/ \mathrm{yr}\right)$. It is only 1 -

$4 \%$ of previous estimates of organic carbon burial in marine sediment $\left(1.6-6.5 * 10^{13}\right.$ mol C/yr) $(30,31)$, equivalent to $\left.6.4 * 10^{13}-2.6^{*} 10^{14} \mathrm{~mol} \mathrm{e}-/ \mathrm{yr}\right)$. To a first approximation, these results indicate most organic carbon that reaches the seafloor is oxidized in the top 1.5 meters of marine sediment $\left(\sim 6.4-7.3 * 10^{14} \mathrm{~mol} \mathrm{e}-/ \mathrm{yr}\right)(30,31)$, not in the subseafloor. Additionally, these results indicate that most organic matter in subseafloor sediment below $1.5 \mathrm{~m}$ does not get consumed.

Spatial variation in respiration of the subseafloor sedimentary ecosystem broadly mirrors spatial variation in community respiration of the ocean (compare to Wilson et al., 2014)(32). In both cases, respiration rates are highest along continental margins and at the equator, and lowest in or beneath ocean gyres. In part, these patterns mirror each other because rates of community respiration in the ocean and subseafloor net respiration are both influenced by rates of photosynthetic primary production in the ocean (which is indirectly represented by sea-surface chlorophyll-a as our second predictor of net subseafloor respiration). Moreover, they mirror each other because organic burial rate depends on sediment accumulation rate $(6,18)$ 
(Table 1) and sediment accumulation rate tends to co-vary with marine primary production.

Buried organic matter serves as the main electron donor for net respiration in subseafloor sediment. Where sedimentation rates are high, burial rates of organic matter and dissolved electron acceptors are rapid, sustaining relatively high net respiration in subseafloor sediment. In contrast, where sedimentation rates are low, most organic flux to the seafloor is consumed in very shallow sediment, leaving much less organic matter to support net respiration by the subseafloor ecosystem (6). Sediment accumulation rates tend to be highest in regions where marine productivity is high (e.g., along continental margins, where upwelling of deep water sustains high photosynthetic biomass production and there is large terrigenous input of both sediment and organic matter) and lowest in regions where marine productivity is low (e.g., the abyssal sediment of mid-ocean gyres, where there is very little upwelling to sustain photosynthetic biomass production, very little planktonic biomineralization, and almost no input of terrigenous sediment). Sedimentation rate is even lower in sediment deposited below the carbonate compensation depth (where calcium carbonate particles secreted by marine plankton in the photic zone are dissolved in the deep water and near-seafloor sediment).

Although it explicitly includes both $\mathrm{SO}_{4}{ }^{2-}$ reduction and $\mathrm{O}_{2}$ reduction, our global estimate of net respiration in subseafloor sediment $\left(2.6^{*} 10^{12} \pm 0.25^{*} 10^{12}\right.$ mol $\mathrm{e}^{-}$ /yr) is much lower than published estimates of total sulfate reduction in marine sediment $\left[9.04 * 10^{13} \mathrm{~mol} \mathrm{e} / \mathrm{yr}(17)\right.$ to $\left.7.5^{*} 10^{14} \mathrm{~mol} \mathrm{e} / \mathrm{yr}(20)\right]$. This difference between net subseafloor respiration and global $\mathrm{SO}_{4}{ }^{2-}$ reduction may primarily result from the 
considerable rate of global $\mathrm{SO}_{4}{ }^{2-}$ reduction in sediment shallower than $1.5 \mathrm{mbsf}$. Additionally, the highest $\mathrm{SO}_{4}{ }^{2-}$ reduction estimate $\left(7.5^{*} 10^{14} \mathrm{~mol} \mathrm{e}-/ \mathrm{yr}\right)$ includes data from near-shore sites (which are under-represented in our data, and where most $\mathrm{SO}_{4}{ }^{2-}$ reduction occurs at shallow sediment depths) and uses rates from radiosulfur experiments (potential rates) as a proxy for in situ rates.

Estimated mean per-cell rates of net (organic-fueled) respiration in subseafloor sediment are much slower than in seafloor sediment or laboratory cultures (e.g., ref. 4$6,8,12,17,18)$. For example, in study of a North Pacific Gyre site, Røy et al. (2012) (6) found average per-cell $\mathrm{O}_{2}$-reduction rates to decrease with depth and stabilize at ca. $1.5^{*} 10^{-15} \mathrm{~mol} \mathrm{e} / \mathrm{cell} / \mathrm{yr}$ at $10 \mathrm{mbsf}$. On a global basis, our average per-cell $\mathrm{O}_{2-}$ reduction rates exhibit a range between $1.0^{*} 10^{-16}$ and $5.8^{*} 10^{-14} \mathrm{~mol} \mathrm{e} / \mathrm{cell} / \mathrm{yr}$ (Figure 2B). Bowles et al. (2014) (17) used their estimated global distributions of $\mathrm{SO}_{4}{ }^{2-}-$ reduction rates and the global cell-count distributions of Kallmeyer et al. (2012) (1) to estimated average per-cell $\mathrm{SO}_{4}{ }^{2-}$-reduction rates to geographically range between $2.9 * 10^{-15}$ and $2.9 * 10^{-13} \mathrm{~mol} \mathrm{e} /$ cell/year. Our mean per-cell $\mathrm{SO}_{4}{ }^{2-}$-reduction rates vary more broadly from region to region, ranging between $4.2 * 10^{-19}$ and $1.0^{*} 10^{-15}$ mol $\mathrm{e}^{-}$ /cell/yr (Figure 2B).

Although they approximate gross organic-fueled respiration in subseafloor sediment, net rates of $\mathrm{SO}_{4}{ }^{2-}$ and $\mathrm{O}_{2}$ reduction may not capture all significant electronaccepting activity in the subseafloor sedimentary ecosystem. Water radiolysis produces electron donors and acceptors that may also play a key role in sustaining microbial life in subseafloor sediment $(18,21)$. Radiolytic $\mathrm{H}_{2}$ and radiolytic oxidants are produced in stoichiometric balance (18), and the mass balances described in the 
Results (net $\mathrm{SO}_{4}{ }^{2-}$ reduction vs net DIC production, and net $\mathrm{O}_{2}$ reduction vs net $\mathrm{NO}_{3}{ }^{-}$ production) indicate that consumption of radiolytic products does not significantly affect net respiration in subseafloor sediment.

Electron equivalents of natural radiolytic production of $\mathrm{H}_{2}$ and oxidants in subseafloor sediment are each estimated to approximate $9.8^{*} 10^{12} \mathrm{~mol} \mathrm{e} / \mathrm{yr}(23)$. This is almost a factor of four larger than the global organic-fueled respiration rate we calculate from net reduction of $\mathrm{SO}_{4}{ }^{2-}$ and $\mathrm{O}_{2}$. Comparison of our net respiration map to Sauvage's (2018) global map of radiolytic production (23) indicates that areal production of radiolytic $\mathrm{H}_{2}$ and oxidants exceed net respiration (organic oxidation) in the subseafloor sediment of continental margins and other areas of thick sediment. In contrast, net respiration (organic oxidation) exceeds radiolytic production of $\mathrm{H}_{2}$ and oxidants where sediment is thin (Figure 3). Radiolysis can continually produce electron acceptors and donors from the sediment surface to the basement or $0.1 \%$ porosity (23). On the other hand, pore water profiles suggest respiration through organic matter oxidation rarely persists at high rates beyond the top $100 \mathrm{~m}$ of sediment (Supplemental Figure 2), leaving radiolysis to be responsible for much more of the energy generation in subseafloor sediment.

Combining our global net respiration map and the Sauvage (2018) global map of radiolytic chemical production (23) yields a global map of depth-integrated total potential respiration in subseafloor sediment (Figure 2C). The global sum of these processes in subseafloor sediment is ca. $1.3^{*} 10^{13} \mathrm{~mol} \mathrm{e} / \mathrm{yr}$. This combined rate is low relative to the dominant biological processes on Earth's surface (32-34). For example, 
it is roughly 10,000 times lower than the rate of photosynthetic carbon fixation in the ocean $\left(1.2 * 10^{17} \mathrm{~mol} \mathrm{e} / \mathrm{yr}\right)(35)$.

Addition of potential radiolysis-supported respiration to the net (organicfueled) respiration that we calculate has a relatively small effect on our estimates of mean per-cell respiration (compare Figure 2B to Figure 2D). Average per-cell rates for net respiration ranged between $4.2^{*} 10^{-19}$ and $5.8^{*} 10^{-14} \mathrm{~mol} \mathrm{e} / \mathrm{cell} / \mathrm{yr}$, while the mean per-cell rates for total respiration range from $3.3^{*} 10^{-18}$ to $2.2^{*} 10^{-13} \mathrm{~mol} \mathrm{e} / \mathrm{cell} / \mathrm{yr}$. Both ranges are generally far below per-cell $\mathrm{SO}_{4}{ }^{2-}$-reduction rates in near-seafloor sediment and $\mathrm{SO}_{4}{ }^{2-}$-reducing bacterial cultures (respectively $\sim 10^{-14}$ and $10^{-10}$ to $10^{-12} \mathrm{~mol} \mathrm{e}^{-}$ /cell/yr $(4,8,36))$.

These results provide the first global estimate of net (organic-fueled) respiration in subseafloor sediment $-2.56^{*} 10^{12} \mathrm{~mol} \mathrm{e}-/ y r$. Anaerobic respiration dominates in subseafloor sediment over ca. $65 \%$ of the seafloor, but contributes up to $94 \%$ of total net respiration in subseafloor sediment. Net respiration rates are lowest in abyssal sediment, where aerobic respiration dominates. Net respiration rates are highly variable but consistently higher where anaerobic respiration dominates, such as along continental margins and in equatorial regions. Mean per-cell respiration rates are generally highest at sites where aerobic respiration dominates due to the low cell density in these areas and lowest where anaerobic respiration dominates, due to the higher cell densities in these areas. Radiolysis-supported respiration may dominate over net organic-fueled respiration in the subseafloor sediment of most oceanic regions, and globally averaged by almost a factor of four. Whether radiolytic products are considered or not, throughout the globe subseafloor sedimentary communities 
survive at mean per-cell respiration rates that are orders of magnitude slower than mean per-cell rates in surface environments and the subseafloor sedimentary environment remains one of the most energy-limited on Earth.

\section{MATERIALS AND METHODS}

\section{$\underline{\text { Reaction Rate Analysis }}$}

Sediment porewater profiles of dissolved oxygen, sulfate, and inorganic carbon were analyzed using the numerical procedures and MatLab program from the Wang et al. (2008) reaction-transport model (19). The reaction rate of the sediment column beginning at 1.5 meters below seafloor (mbsf) were calculated and used for all further analyses to avoid the effect of bioturbation on the uppermost section of the chemical profiles. All depth-integrated reaction rates (e.g., moles $\mathrm{O}_{2} \mathrm{~m}^{-2}$ year ${ }^{-1}$ ) were converted to respiration rates or electron transport rates (e.g. moles of electrons $\mathrm{m}^{-2}$ year ${ }^{-1}$ ) by assuming the transfer of 4 electrons per $\mathrm{O}_{2}$ molecule reduced, and 8 electrons per $\mathrm{SO}_{4}{ }^{2-}$ molecule reduced. This conversion to electron transport rates allows for the direct comparison between oxic and anoxic sites.

\section{Model Map Development}

Data sites were split into two physiographic regions using cutoff water depths of less than 2000 meters for margin sites and greater than 2000 meters for abyssal sites. Sites located on seamounts breaching the $2000 \mathrm{~m}$ water depth cutoff were removed from the regression analysis. We used SPSS Statistics software (v24.0) to run a multiparametric backstepping regression analysis to determine, via the $\mathrm{R}^{2}$ value, that a linear relationship between sedimentation rate, sea surface chlorophyll- $a$, and 
respiration rates create a regression line that best fits the actual electron transport rate data for both margin regions $\left(\mathrm{R}^{2}=0.84\right)$ and abyssal regions $\left(\mathrm{R}^{2}=0.76\right)$ (Table 1$)$.

Grids of sedimentation rate and sea surface chlorophyll- $a$ were manipulated according to the regression equations (Table 1) to develop a global map of respiration rate in subseafloor sediment (Figure 1A). The residuals were plotted beneath a normal distribution curve calculated from the appropriate standard deviation to ensure a normal distribution of residuals (Figure 1B).

The map of respiration through organic matter oxidation was directly compared to the Kallmeyer et al. (2012) cell count map (1) to determine the global distribution of average per-cell rates of respiration through organic matter oxidation (Figure 2B). The respiration map was also directly compared to the Sauvage (2018) global map of radiolytic hydrogen production (23) (Figure 3) and the two were combined to produce a map of total respiration (Figure 2C). Finally, the map of total respiration was compared to the Kallmeyer et al. (2012) cell count map (1) to determine the global distribution of average per-cell rates of total respiration (Figure 2D). For more details on grid manipulation and these comparisons, refer to the SI Text. 


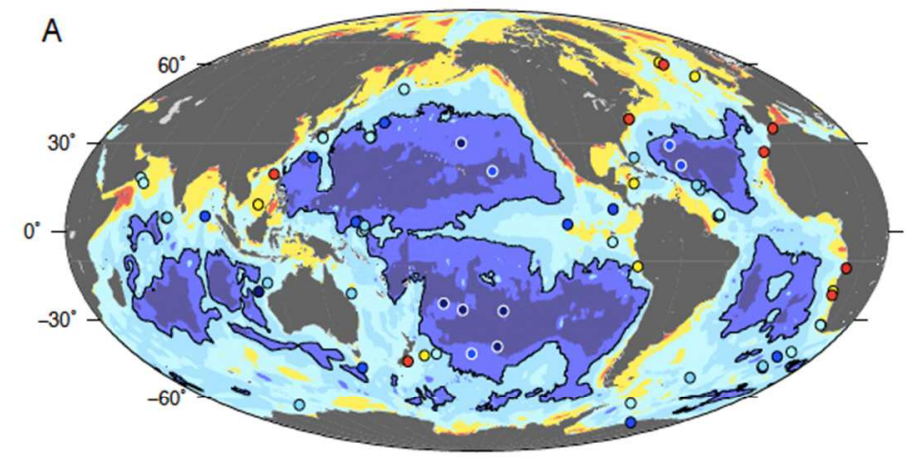

B
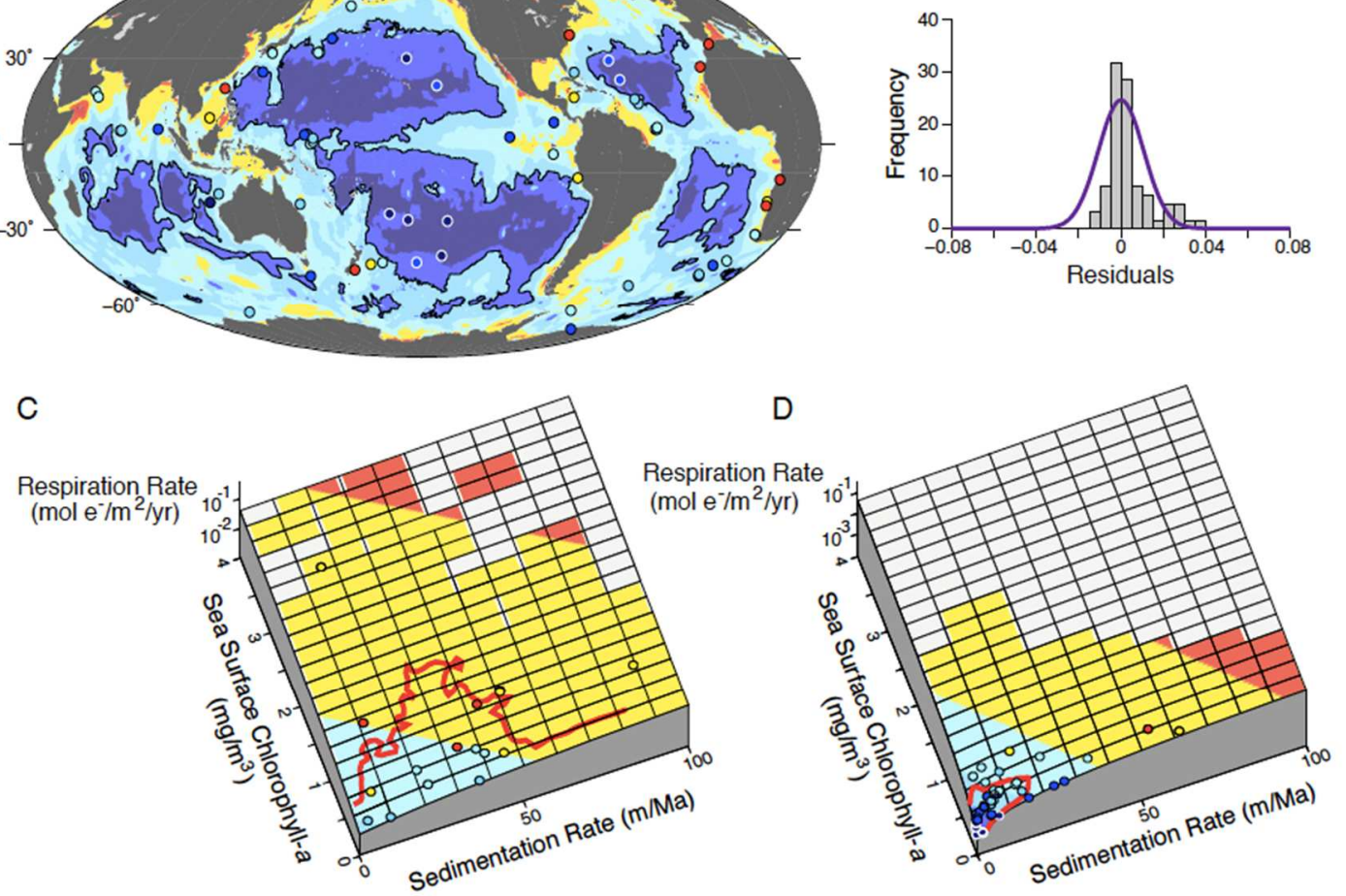
$\left(\mathrm{mol} \mathrm{e}^{-} / \mathrm{m}^{2} / \mathrm{yr}\right)$

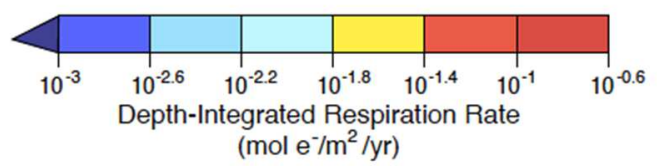

Figure 1. Global distribution of subseafloor sedimentary net respiration rate $\left(\mathrm{mol} \mathrm{e} / \mathrm{m}^{2} / \mathrm{yr}\right)(\mathbf{A})$. Background colors on all plots represent modeled respiration rates denoted by the color bar. Dot colors indicate calculated respiration rates for individual sites (based on dissolved chemical measurements and sediment properties). Dots of the two darkest blues are where aerobic respiration occurs. Within the black contour line is where aerobic respiration is predicted to occur, and outside of the black contour is where anaerobic respiration is predicted to occur (A). Model residuals are normally distributed beneath the purple normal distribution curve, calculated from the standard deviation (B). The model is based on sedimentation rate and sea surface chlorophyll-a for both shallow $(<2000 \mathrm{~m})(\mathbf{C})$ and abyssal $(>2000 \mathrm{~m})$ (D) regions. $50 \%$ of the naturally occurring sedimentation rate and chlorophyll- $a$ fall within the red contour $(\mathbf{C}$ and D). Gray regions denote combinations of chlorophyll-a and sedimentation rate that are not naturally occurring (C and $\mathbf{D})$. 
Table 1.

Coefficients of determination $\left(\mathrm{R}^{2}\right)$ for variables used in a multiparametric backstepping regression analysis. Best fit equation parameters for chosen variables.

\begin{tabular}{|l|l|l|}
\hline \multicolumn{2}{|c|}{$\mathrm{R}^{2}$ for various parameters in multiparametric backstepping regression analysis } \\
\hline & $\begin{array}{l}\text { Shallow } \\
(<2000 \mathrm{~m} \text { water depth) }\end{array}$ & $\begin{array}{l}\text { Abyssal } \\
(>2000 \mathrm{~m} \text { water depth) }\end{array}$ \\
\hline Sedimentation rate & 0.83 & 0.75 \\
\hline Sea surface chlorophyll-a & 0.06 & 0.12 \\
\hline Water depth & 0.05 & 0.08 \\
\hline Distance from land & 0.28 & 0.17 \\
\hline Sea surface temperature & 0.01 & 0.00 \\
\hline $\begin{array}{l}\text { Sedimentation rate and } \\
\text { sea surface chlorophyll- } a\end{array}$ & 0.84 & 0.76 \\
\hline $\begin{array}{l}\text { Sedimentation rate and } \\
\text { distance from land }\end{array}$ & 0.82 & 0.74 \\
\hline $\begin{array}{l}\text { Sedimentation rate, } \\
\text { distance from land, and } \\
\text { sea surface chlorophyll- } a\end{array}$ & 0.84 & 0.74 \\
\hline \multicolumn{2}{|l|}{ Best-fit equation parameters } & $4.3 * 10^{-4}$ \\
\hline $\begin{array}{l}\text { Sedimentation rate coefficient } \\
\text { (m1) }\end{array}$ & $2.0^{*} 10^{-4}$ & $1.1 * 10^{-2}$ \\
\hline $\begin{array}{l}\text { Sea surface chlorophyll- } a \\
\text { coefficient (m2) }\end{array}$ & $7.8 * 10^{-3}$ & $-4.3 * 10^{-4}$ \\
\hline $\begin{array}{l}\text { Constant (b) } \\
\text { (Roefficient of determination }\end{array}$ & 0.84 & 0.76 \\
\hline Data sources are provided & $4.9 * 10^{-3}$ & \\
\hline
\end{tabular}

*Data sources are provided in SI Text 

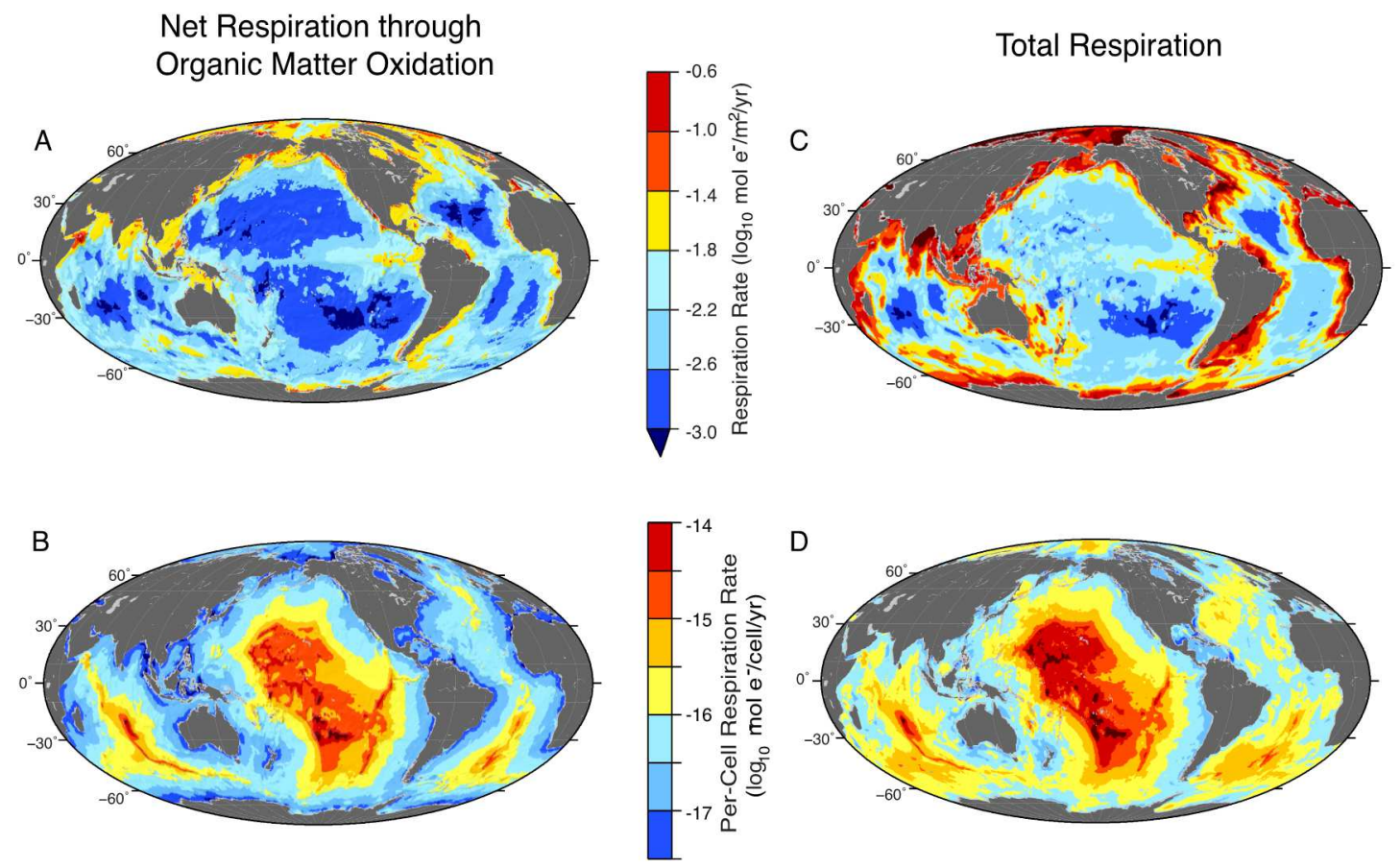

Figure 2. Global distribution of mean per-cell respiration rates below $1.5 \mathrm{mbsf}$ (mol e-/cell/yr) (B and D) calculated from the global distribution of cell abundance below 1.5 mbsf, modified from Kallmeyer et al. (2012) and the global distribution of net respiration rates below $1.5 \mathrm{mbsf}(\mathbf{A})$ or potential total respiration (net respiration plus potential radiolysis-fueled respiration) rates below $1.5 \mathrm{mbsf}(\mathbf{C})$. 


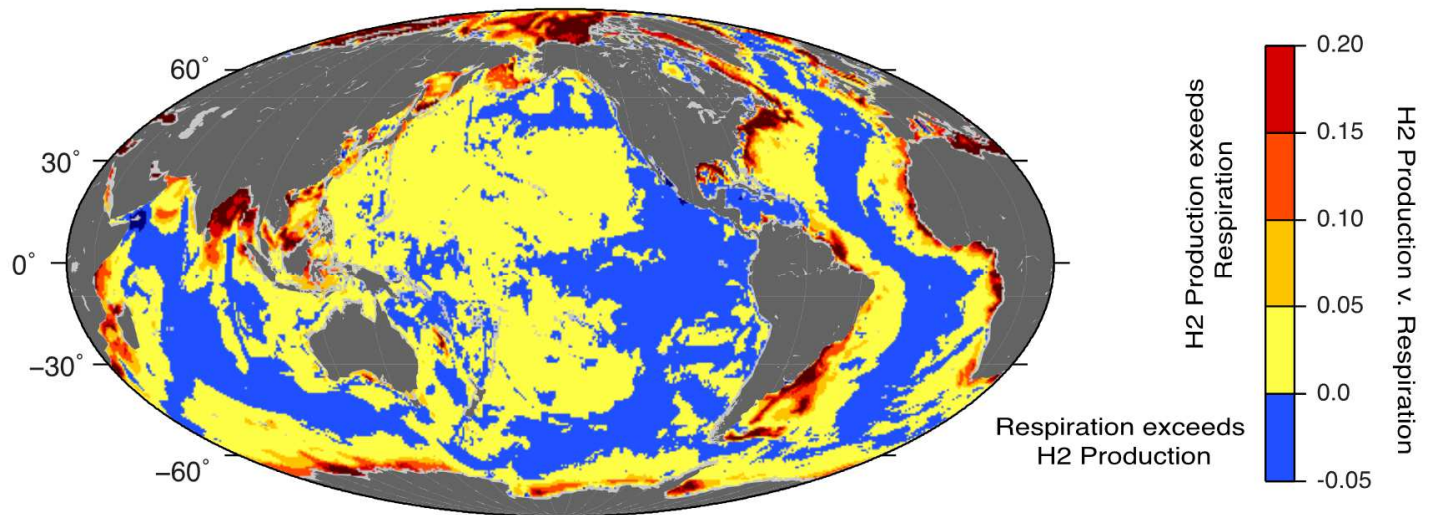

Figure 3. The relative difference between globally predicted radiolytic hydrogen production (Sauvage, 2018) and net respiration in subseafloor sediment. Net respiration exceeds hydrogen production in blue regions. Red and yellow regions denote where radiolytic hydrogen production most and least outweighs net respiration, respectively. 


\section{REFERENCES}

1. J. Kallmeyer, R. Pockalny, R. R. Adhikari, D. C. Smith, S. D'Hondt, Global distribution of microbial abundance and biomass in subseafloor sediment. Proceedings of the National Academy of Sciences of the United States of America 109, 16213-16216 (2012).

2. R. J. Parkes, et al., Bacterial Biomass and Activity in Deep Sediment Layers from the Peru Margin. Philosophical Transactions of the Royal Society A: Mathematical, Physical and Engineering Sciences 331, 139-153 (1990).

3. B. A. Lomstein, A. T. Langerhuus, S. D’Hondt, B. B. Jørgensen, A. J. Spivack, Endospore abundance, microbial growth and necromass turnover in deep subseafloor sediment. Nature 484, 101-104 (2012).

4. S. D'Hondt, S. Rutherford, A. J. Spivack, Metabolic Activity of Subsurface Life in Deep-Sea Sediments. Science 295, 2067-2070 (2002).

5. S. D'Hondt, et al., Subseafloor sedimentary life in the South Pacific Gyre. Proceedings of the National Academy of Sciences of the United States of America 106, 11651-11656 (2009).

6. H. Røy, et al., Aerobic Microbial Respiration in 86-Million-Year-Old Deep-Sea Red Clay. Science 336, 922-925 (2012).

7. S. D'Hondt, et al., Distributions of Microbial Activities in Deep Subseafloor Sediments. Science 306, 2216-2221 (2004).

8. S. D'Hondt, G. Wang, A. Spivack, “The underground economy (Energetic Constraints of Subseafloor Life)" in Earth and Life Processes Discovered from Subseafloor Environments : A Decade of Science Achieved by the Integrated Ocean Drilling Program (IODP), H.-C. Stein, Ruediger Blackman, Donna K. Inagaki, Shisei Larsen, Ed. (Elsevier, 2014), pp. 127-148.

9. B. B. Jørgensen, S. D'Hondt, A Starving Majority Deep Beneath the Seafloor. Science, 932-934 (2006).

10. B. B. Jørgensen, A. Boetius, Feast and famine - microbial life in the deep-sea bed. Nature Reviews Microbiology 5, 770-781 (2007).

11. S. D'Hondt, et al., Presence of oxygen and aerobic communities from sea floor to basement in deep-sea sediments. Nature Geoscience 8, 299-304 (2015).

12. T. M. Hoehler, B. B. Jørgensen, Microbial life under extreme energy limitation. Nature Reviews Microbiology 11, 83-94 (2013).

13. J. M. Gieskes, Chemistry of Interstitial Waters of Marine Sediments. Annual Review of Earth and Planetary Sciences 3, 433-453 (1975).

14. G. R. Dickens, M. Koelling, D. C. Smith, L. Schnieders, Rhizon Sampling of Pore Waters on Scientific Drilling Expeditions: An Example from the IODP Expedition 302, Arctic Coring Expedition (ACEX). Scientific Drilling (2007) https:/doi.org/10.2204/iodp.sd.4.08.2007.

15. C. Knoblauch, B. B. Jørgensen, J. Harder, Community size and metabolic rates of psychrophilic sulfate-reducing bacteria in Arctic marine sediments. Applied and environmental microbiology 65, 4230-4233 (1999).

16. J. Leloup, et al., Sulfate-reducing bacteria in marine sediment (Aarhus Bay, Denmark): abundance and diversity related to geochemical zonation.

Environmental Microbiology 11, 1278-1291 (2009). 
17. M. W. Bowles, J. M. Mogollón, S. Kasten, M. Zabel, K.-U. Hinrichs, Global rates of marine sulfate reduction and implications for sub-sea-floor metabolic activities. Science (New York, N.Y.) 344, 889-91 (2014).

18. S. D'Hondt, R. Pockalny, V. M. Fulfer, A. J. Spivack, Subseafloor life and its biogeochemical impacts. Nature Communications 10, 3519 (2019).

19. G. Wang, et al., Quantification of co-occurring reaction rates in deep subseafloor sediments. Geochimica et Cosmochimica Acta 72, 3479-3488 (2008).

20. B. B. Jørgensen, S. Kasten, "Sulfur cycling and methane oxidation" in Marine Geochemistry, 2nd Ed., H. D. Schulz, M. Zabel, Eds. (Springer, Berlin, 2006), pp. 271-309.

21. C. C. Blair, S. D'Hondt, A. J. Spivack, R. H. Kingsley, Radiolytic Hydrogen and Microbial Respiration in Subsurface Sediments. Astrobiology 7, 951-970 (2007).

22. A. Türke, K. Nakamura, W. Bach, Palagonitization of Basalt Glass in the Flanks of Mid-Ocean Ridges: Implications for the Bioenergetics of Oceanic Intracrustal Ecosystems. Astrobiology 15, 793-803 (2015).

23. J. Sauvage, Sedimentary Catalysis of Radiolytic Hydrogen Production. Open Access Dissertations (2018).

24. R. D. Müller, M. Sdrolias, C. Gaina, W. R. Roest, Age, spreading rates, and spreading asymmetry of the world's ocean crust. Geochem. Geophys. Geosyst 8150 (2008).

25. G. Laske, G. A. Masters, A global digital map of sediment thickness. Eos Trans. $A G U 78$ (1997).

26. G. Laske, G. A. Masters, Z. Ma, M. Pasvanos, Update on CRUST1.0 - A 1degree Global Model of Earth's Crust. Geophysical Research Abstracts 15 (2013).

27. O. B. P. Group, MODIS Aqua Level 3 Global Monthly Mapped 4 km Chlorophyll a v2014.0 (2015).

28. W. B. F. Ryan, et al., Global Multi-Resolution Topography synthesis. Geochemistry, Geophysics, Geosystems 10, n/a-n/a (2009).

29. R. W. Reynolds, N. A. Rayner, T. M. Smith, D. C. Stokes, W. Wang, An Improved In Situ and Satellite SST Analysis for Climate. Journal of Climate (2002).

30. J. L. Sarmiento, N. Gruber, Ocean biogeochemical dynamics (Princeton University Press, 2006).

31. J. P. Dunne, J. L. Sarmiento, A. Gnanadesikan, A synthesis of global particle export from the surface ocean and cycling through the ocean interior and on the seafloor. Global Biogeochemical Cycles 21 (2007).

32. J. M. Wilson, R. Severson, J. M. Beman, Ocean-Scale Patterns in Community Respiration Rates along Continuous Transects across the Pacific Ocean. PLoS ONE 9, e99821 (2014).

33. W. H. Schlesinger, J. A. Andrews, Soil respiration and the global carbon cycle. Biogeochemistry 48, 7-20 (2000).

34. P. A. del Giorgio, C. M. Duarte, Respiration in the open ocean. Nature 420, 379-384 (2002). 
35. M. J. Behrenfeld, P. G. Falkowski, Photosynthetic rates derived from satellite $\square$ based chlorophyll concentration. Limnology and Oceanography 42, 1-20 (1997).

36. B. B. Jørgensen, A. J. Findlay, A. Pellerin, The Biogeochemical Sulfur Cycle of Marine Sediments. Frontiers in Microbiology 10, 849 (2019). 


\section{APPENDICES}

\section{Supplemental Information}

\section{Porewater chemical data}

Dissolved chemical measurements $\left(\mathrm{SO}_{4}{ }^{2-}, \mathrm{O}_{2}\right.$, DIC) from ocean drilling cruises and coring cruises were downloaded and compiled from the Scientific Earth Drilling Information Service (SEDIS), the Biological and Chemical Data Management Office (BCO-DMO), and the Janus Database. We also collected relevant metadata from each drillsite or coring site (e.g., latitude, longitude, water depth, depth cored, available age models).

\section{QA/QC of dissolved chemical measurements}

We plotted and examined the dissolved $\mathrm{O}_{2}$ and $\mathrm{SO}_{4}{ }^{2-}$ measurement profiles from each site to ensure the quality of the reaction-rate results used to create our global model. Through this exercise, we culled any sites that contain profiles characterized by one or more of the following criteria: (i) fewer than 5 total data points; (ii) missing data from the top 10 meters of sediment; (iii) anomalously high variability in downcore measurements; (iv) evidence of upward advection; or (v) location on a seamount or near evidence of turbiditic activity. To determine the latter, we used cruise report site descriptions and GeoMapApp (v3.6.6, 2017) to analyze the seafloor morphology near each study site.

\section{Global grids of environmental parameters}

Each site has unique environmental characteristics, including basement age, sea-surface chlorophyll- $a$, sedimentation rate, distance from land, and sea-surface temperature (Muller et al., 2008; Ocean Biology Processing Group, 2015; Laske et al., 
1997; Laske et al, 2013; Reynolds et al., 2002). For each published global grid of these parameters, we used the latitude and longitude coordinates of each site to extract the relevant data from the grid using grdtrack in Generic Mapping Tools (GMT) (v5.4.2, 2017). For sea-surface temperature (NOAA_OI_SST_V2 data provided by the NOAA/OAR/ESRL PSD, Boulder, Colorado, USA) and sea-surface chlorophyll- $a$, we compiled archived data to create ten-year average grids.

\section{Creation of the sedimentation rate grid}

Using published age-model (Muller et al., 2008) and sediment thickness (Laske et al., 2013) grids, we created a preliminary global grid of mean sedimentation rates (sediment thickness / age). This preliminary grid was characterized by anomalously high sedimentation rates on areas of young seafloor, due to division of sediment thickness by very small age values. To minimize this effect on our final results, we used GMT to mask younger parts of the seafloor with age limits $(4,10,20$, and $25 \mathrm{Myr}$ ) that vary with spreading rate. For instance, slow-spreading ridges were masked to 20 or $25 \mathrm{Myr}$, and intermediate- and fast-spreading ridges were masked to 10 and 4 Myr, respectively. The resultant masked values were replaced using a variable tension 2D spline with the mask applied to the initial sedimentation rate grid.

\section{Reaction rate analysis}

We used the MatLab program (version 8.3.0) and numerical procedures from Wang et al. (2008) to calculate vertical distributions of in situ reaction rates from 1.5 mbsf to the deepest sampled depth in the sediment column, for dissolved $\mathrm{SO}_{4}{ }^{2-}, \mathrm{O}_{2}$, and inorganic carbon $\left(\mathrm{DIC}=\mathrm{CO}_{2}+\mathrm{HCO}_{3}{ }^{-}+\mathrm{CO}_{3}{ }^{2-}\right)($ Supplemental Figure 2). This required the input of the dissolved chemical concentrations and mean sedimentation 
rates that were calculated using the Crust 1.0 sediment thickness model (Laske et al., 2013) and the Chronos portal basement age model. The program also required input of physical properties such as in situ temperature, formation factor, and sediment porosity. We derived the necessary diffusion coefficients from in situ temperature data and the diffusion coefficients at standard temperatures (Schulz and Zabel, 2006).

The Wang et al. (2008) reaction-transport program relies on a user-defined minimum number of data points to define each reaction zone. We experimented with the size of these zones, ranging from 3 to 15 data points, and chose the most appropriate option for each site, based on the fit to the initial $\mathrm{SO}_{4}{ }^{2-}$ and $\mathrm{O}_{2}$ data measurement profiles and the uncertainties of the calculated reaction rates. The program identifies the maximum number of depth intervals in each chemical profile with statistically different reaction rates $(\alpha=0.05)$ and calculates the mean reaction rate for each depth interval. We used a Monte Carlo method with fifty iterations to quantify the uncertainties in the calculated reaction rates at each zone.

We accounted for the fluxes from the omitted $1.5 \mathrm{~m}$ section by extrapolating the values at $1.5 \mathrm{mbsf}$ to the sediment water interface.

To directly compare aerobic respiration rates to anaerobic rates, we converted all reaction rates (e.g., mol $\mathrm{O}_{2} / \mathrm{m}^{2} / \mathrm{yr}$ ) to electron equivalents (mol e $/ \mathrm{m}^{2} / \mathrm{yr}$ ) by assuming the transfer of 4 electrons per $\mathrm{O}_{2}$ molecule reduced, and 8 electrons per $\mathrm{SO}_{4}{ }^{2-}$ molecule reduced.

\section{Multivariate regression analysis}

After converting all respiration rates to electron-equivalent rates, we used the SPSS Statistics software (v24.0) for a backstepping multiparametric regression 
analysis. This analysis determined which independent variables (e.g., sedimentation rate, sea surface chlorophyll- $a$, distance from land, etc.) best capture the variability in respiration rate. The backstepping regression determined the linear best fit with sedimentation rate and sea surface chlorophyll- $a$, with sedimentation rate being the predominant driver of variance in the model. Distance from land also describes some of the variance, however the addition of this variable to the regression model does not increase the total amount of variance in respiration rate the model can explain. Additionally, using a logarithmic relationship between respiration rate and chlorophyll-a does not significantly impact the $\mathrm{R}^{2}$ value or the model values.

We also identified a difference in the data trends for sites in shallow water relative to sites in deep water, especially when it came to sedimentation rate. Therefore, we experimentally split the sites into two regions, using various depth cutoffs between 1000 and 4000m water depth. We discovered that the regression analysis worked best when the data was split into "margin" sites, with $<2000$ m water depth, and abyssal sites, with water depth $>2000 \mathrm{~m}$. Sites on seamounts in water shallower than $2000 \mathrm{~m}$ were removed from the regression analysis. Of the examined variables, linear fits to mean sedimentation rate and sea surface chlorophyll- $a$ exhibit the highest correlation to respiration rates in both margin regions $\left(\mathrm{R}^{2}=0.84\right)$ and abyssal regions $\left(\mathrm{R}^{2}=0.76\right)$, with mean sedimentation rate being the predominant driver of variation in this model. When non-linear fit possibilities were examined, no non-linear fit options exhibited a higher $\mathrm{R}^{2}$ than the linear fits. 


\section{Creation of the Global Model}

The output of the above statistical analysis resulted in a regression surface for each region (Equations S1 and S2), where SR is sedimentation rate and CHL is sea surface chlorophyll- $a$.

Margin (water depth $<2000 \mathrm{~m}): \mathrm{RR}=0.00020 * \mathrm{SR}+0.0078 * \mathrm{CHL}+0.0049$

Abyssal (water depth $>2000 \mathrm{~m}): \mathrm{RR}=0.00043 * \mathrm{SR}+0.011 * \mathrm{CHL}-0.00043$

Global grids of respiration rate (RR) were calculated with the best-fit regression relationships (S1 and S2) using the sedimentation rate and sea surface chlorophyll- $a$ values from the respective grids and for the appropriate depth range. The margin and abyssal model grids were combined to create a final grid encompassing the entire subseafloor at 0.66 degree resolution.

We then plotted the global model grid and the location of each study site using GMT. We color-coded each site based on its calculated net respiration rate, using the same color scale as the global model. This allowed us to compare how well the model estimates match the site-specific rates.

We calculated the residuals of the model (measured value - modeled value) and standard deviation of 0.05 . We then plotted as a histogram of the residuals and the corresponding normal distribution curve for the appropriate standard deviation. The residuals are normally distributed, and all sites fall within the range of sedimentation rate/sea surface chlorophyll- $a$ combinations that naturally occur in the world ocean (Figure 1). Finally, using grdvolume we calculated a net global respiration rate. 


\section{Model modifications for comparison to global cell abundance and radiolytic chemical production}

For our comparisons to global maps of cell abundance (Kallmeyer et al., 2012) and radiolytic production of electron donors and acceptors (Sauvage, 2018), we extended our net respiration model to the depth of (i) basement, (ii) $0.1 \%$ porosity, or (iii) the $122^{\circ} \mathrm{C}$ isotherm, as appropriate to match the environmental limits of the cellabundance and radiolytic production models. Therefore, for each grid cell, we determined the depths of these three parameters using grdtrack in GMT. We then used an awk statement to determine which of the three cutoff depths was reached first for all locations across the subseafloor. For the respiration model, respiration rates of individual sites were recalculated by extending the final respiration zone identified by the Wang (2008) method for each site to the that first cut-off depth, and then calculating the depth-integrated reaction rate to the cut-off depth. These new values for each site were then run through a regression analysis and a new global model built, as described above. This new model was used for comparisons to the Kallmeyer (2012) and Sauvage (2018) global models of cell abundance and radiolytic chemical production in subseafloor sediment (described below).

\section{Calculation of Per-cell Rates}

We modified the Kallmeyer et al. (2012) global grid of cell abundance by imposing a cutoff at $1.5 \mathrm{mbsf}$ to only includes cells in sediment below this depth, just as our global respiration model does. We also applied a cutoff to the model as necessary, to the depth of basement, $0.1 \%$ porosity, or the $122^{\circ} \mathrm{C}$ isotherm, whichever was shallowest. Using GMT, we converted the grid from cells $/ \mathrm{km}^{2}$ to cells $/ \mathrm{m}^{2}$. We 
then divided our adjusted respiration grid (described above) and the calculated total respiration grid by the cell abundance grid to develop maps of global respiration percell (mol e-/cell/yr)(Figure 2B and 2D). It should be noted that this map is a rough approximation of global respiration per-cell, as both maps are based on models derived from different variables (e.g., sedimentation rate and distance from land (Kallmeyer et al., 2012) vs. sedimentation rate and sea surface chlorophyll-a).

\section{Comparison to DIC production rates}

We quantified net DIC production rates using the same methods as described above for net $\mathrm{SO}_{4}{ }^{2-}$ and $\mathrm{O}_{2}$ reduction rates. These rates were converted to electron equivalents by assuming 4 electrons per mol of DIC produced. When compared to $\mathrm{SO}_{4}{ }^{2-}$ reduction rates, the slope was 1.3 (Supplemental Figure 3). The approximate equivalence of the two rates indicates that net $\mathrm{SO}_{4}{ }^{2-}$ reduction roughly equals net organic oxidation within the sediment. The slight deviation from a strict 1-to-1 relationship may in part result from (i) contribution to DIC production by dissolution of carbonate minerals, (ii) organic oxidation via metal (iron and/or manganese) reduction (e.g., Wang et al., 2010), (iii) DIC production through fermentation in the methanogenic zone, (iv) DIC production occurring below the depth of sulfate reduction, and/or (v) relative high errors and a very small number of sites with high respiration rates (4). We are unable to account for the above variables (i-v), and therefore we expect the slope to be greater than one. 
Comparison to a previous estimate of global distributions of $\mathrm{SO}_{4}{ }^{2-}$ and $\mathrm{O}_{2}$ reduction in subseafloor sediment

In a previous study (D'Hondt et al., 2019), we used published $\mathrm{SO}_{4}{ }^{2-}$ and $\mathrm{O}_{2}$ concentration data to estimate where $\mathrm{SO}_{4}{ }^{2-}$ reduction and $\mathrm{O}_{2}$ reduction respectively dominate net respiration in subseafloor sediment. We directly compared our model output to this published distribution by using GMT to convert the two grids to a binary system denoting grid nodes of oxygen reduction or sulfate reduction. The two grids were then directly compared and color-coded depending on if the areas agreed (e.g., both predicted oxygen reduction at on grid node) or disagreed (e.g., one estimated oxygen reduction and the other sulfate reduction at the same grid node). We found $81 \%$ agreement in the predictions between the two models.

\section{Comparison to global patterns of radiolytic $\mathrm{H}_{2}$ production}

The global grid of radiolytic hydrogen production from Sauvage (2018) was cut off at the depth of basement, $0.1 \%$ porosity, or the $122^{\circ} \mathrm{C}$ isotherm, whichever was shallowest. This grid was converted to $\mathrm{mol} \mathrm{e}^{-} / \mathrm{m}^{2} / \mathrm{yr}$. The resulting radiolysis grid and our adjusted grid of respiration through organic matter oxidation (described above) were added using grdmath in GMT to produce a grid of total respiration (Figure 2C). 


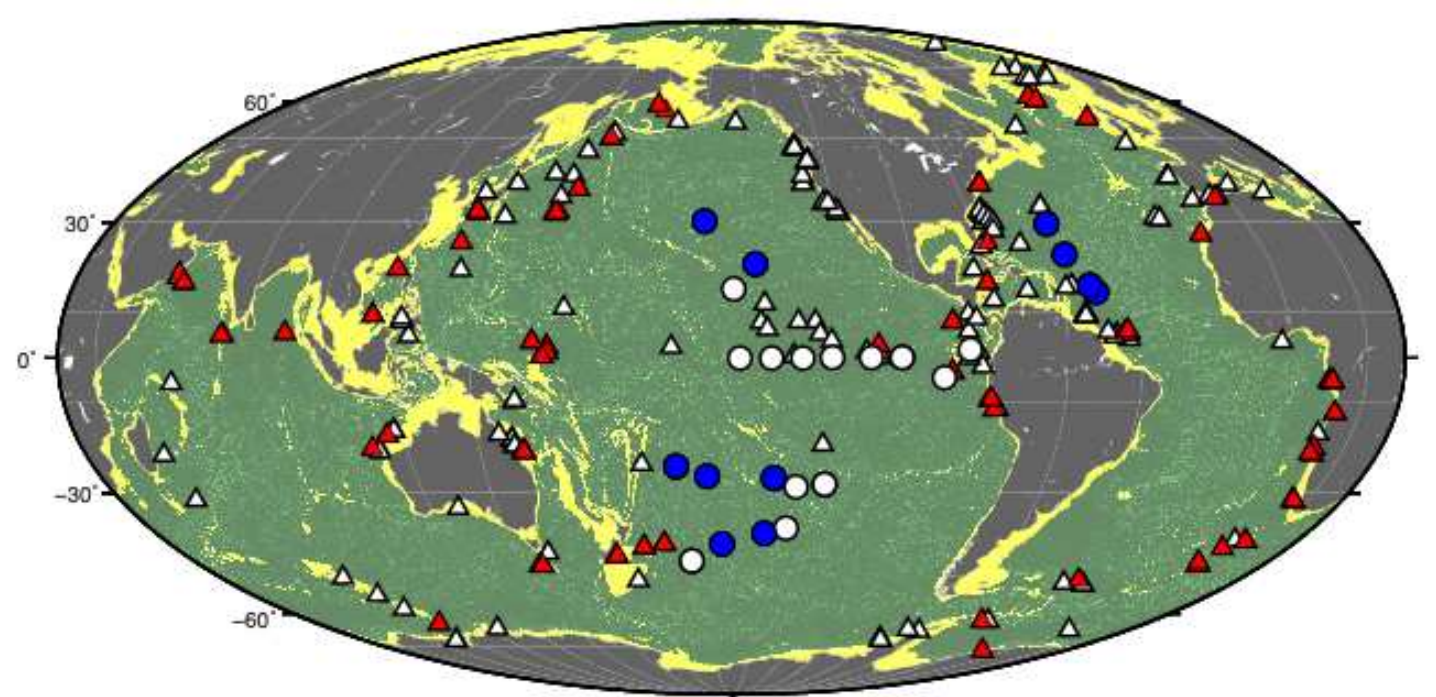

Supplemental Figure 1. The locations of sites used in this study. Circles represent sites with down-core dissolved oxygen concentration measurements and trace sulfate concentrations. Triangles represent sites with down-core dissolved sulfate concentration measurements. Colored symbols identify sites included in the final model for sulfate (red) and oxygen (blue). Yellow and green regions denote the shallow $(<2000 \mathrm{~m})$ and abyssal $(>2000 \mathrm{~m})$ regions respectively. 


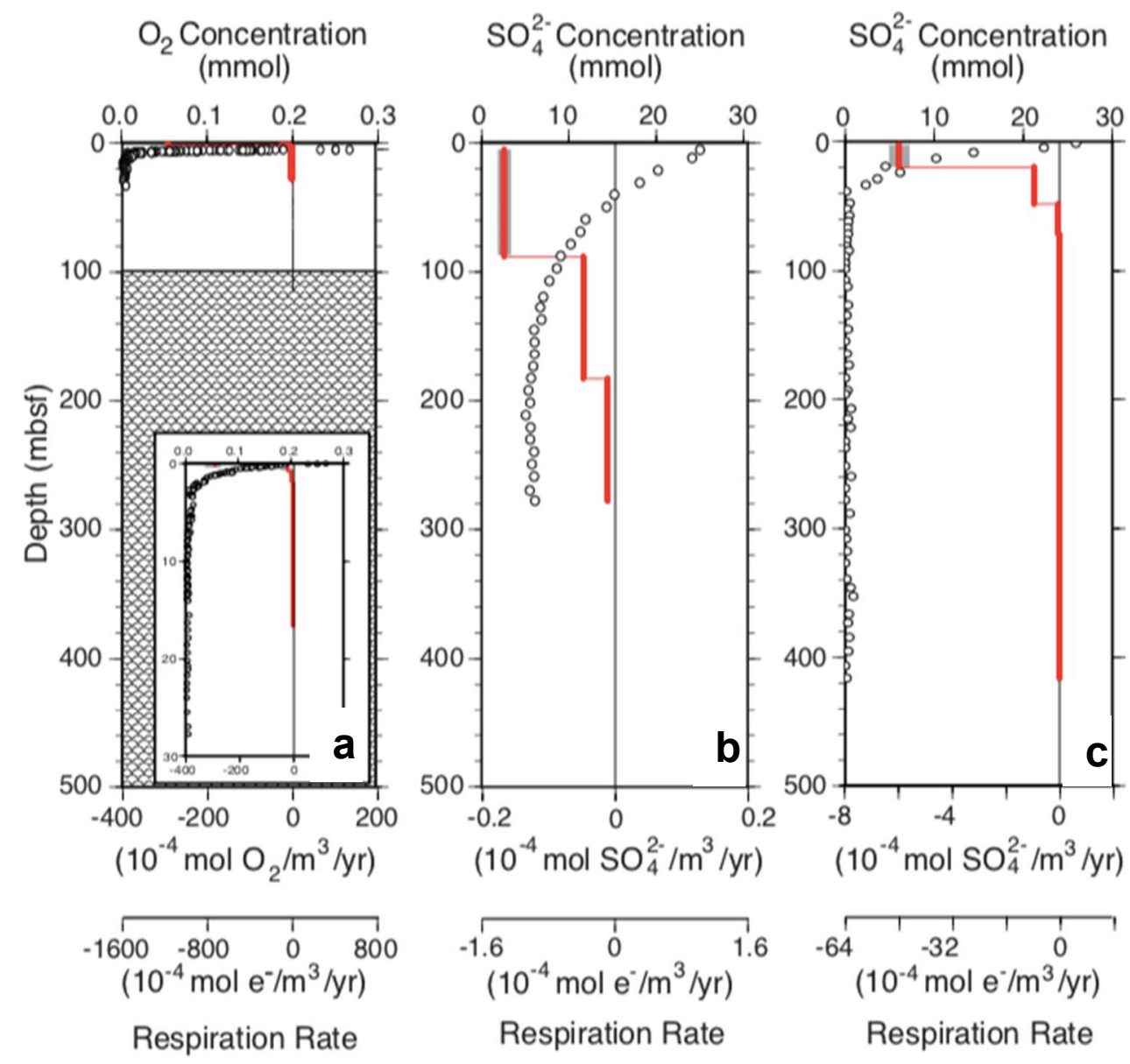

Supplemental Figure 2. Profiles of net respiration rates in sediment. (A) Profile of net $\mathrm{O}_{2}$ reduction (aerobic respiration) rate as a function of sediment depth at site KN223-03. The crosshatched region represents the depth of igneous basement. Inset shows the same profile with an adjusted vertical scale. (B) Profile of net $\mathrm{SO}_{4}{ }^{2-}$ reduction (anaerobic respiration) rate as a function of sediment depth at ODP Site 981. (C) Profile of net $\mathrm{SO}_{4}{ }^{2-}$ reduction rate as a function of sediment depth at ODP Site 1063, where dissolved $\mathrm{SO}_{4}{ }^{2-}$ disappears at a shallow sediment depth. Circles indicate measured $\mathrm{O}_{2}$ or $\mathrm{SO}_{4}{ }^{2-}$ concentrations. Red lines indicate net respiration rates. Gray shaded regions represent uncertainty (one standard deviation) in the respiration rate. 


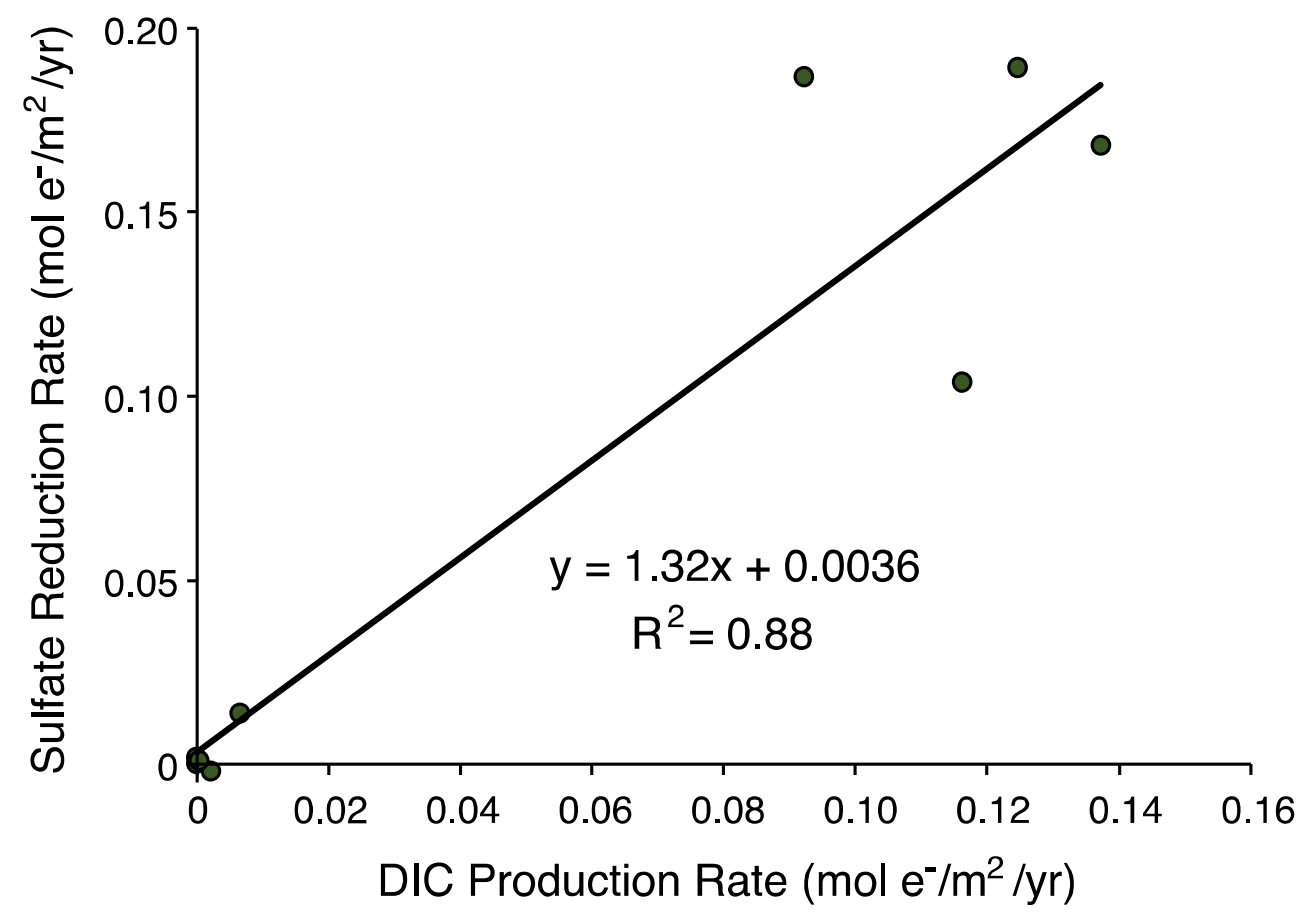

Supplemental Figure 3. The relationship between DIC production rates and sulfate reduction rates at 9 sites. The black line represents a linear best fit with a slope of 1.32 . 

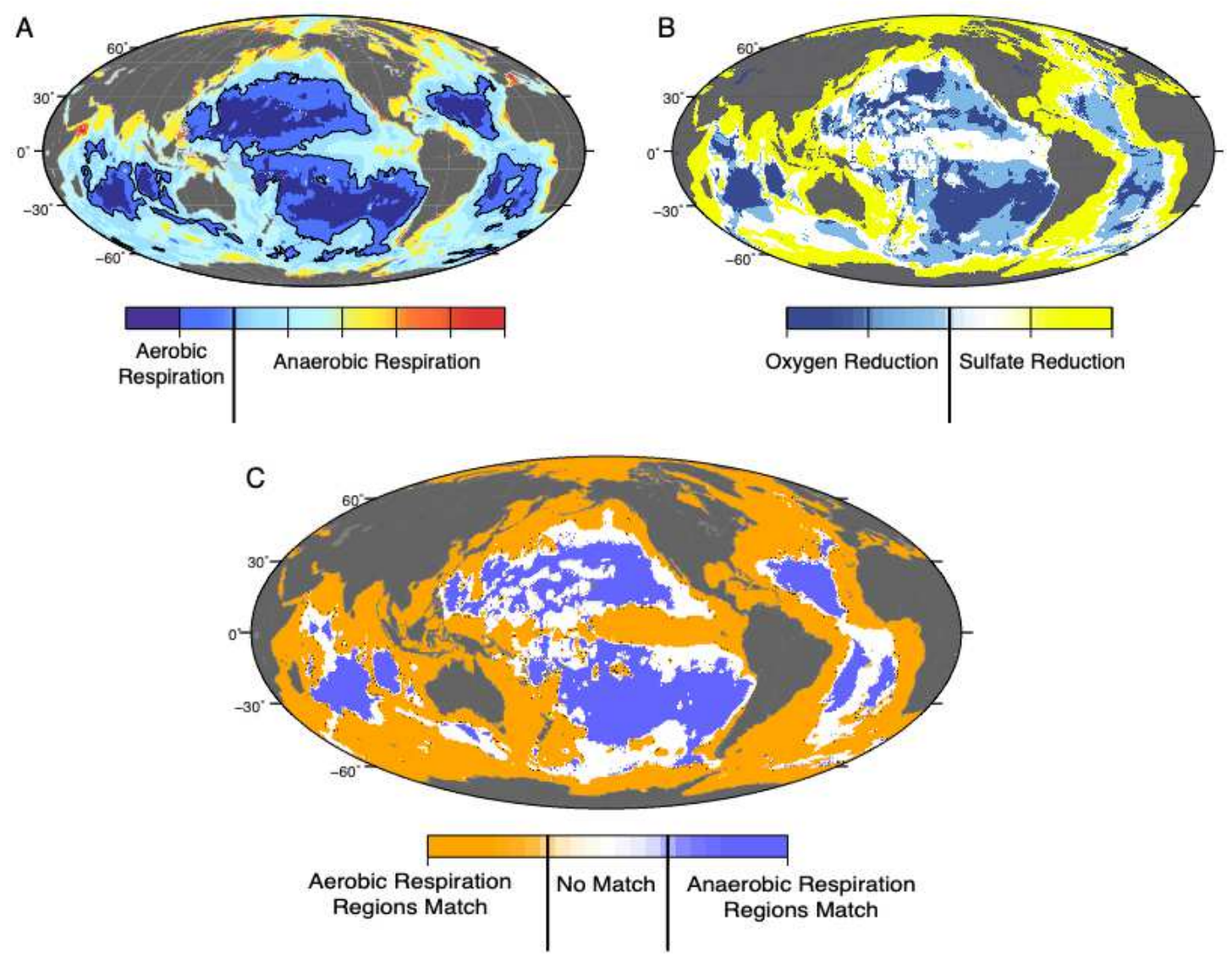

Supplemental Figure 4. Global distribution of subseafloor sedimentary respiration rate $\left(\mathrm{mol} \mathrm{e} / \mathrm{m}^{2} / \mathrm{yr}\right)$. Within the black contour line is where aerobic respiration is predicted to occur. Anaerobic respiration is predicted to occur at all locations outside of the contour (A) Global distribution of dissolved oxygen and sulfate in subseafloor sediment. Oxygen reduction is expected to dominate in blue regions, while sulfate reduction is expected to dominate in white and yellow regions $(\mathbf{B})$. A direct comparison between areas of predicted aerobic and anaerobic respiration in subseafloor sediment, with both models predicting aerobic respiration in orange regions and anaerobic respiration in blue regions. The two models have conflicting predictions in white regions $(\mathbf{C})$. 


\section{REFERENCES}

IODP-MI, Scientific Earth Drilling Information Service - SEDIS. International Ocean Discovery Program. http://sedis.iodp.org/ (Accessed May 13, 2018).

Biological and Chemical Oceanography Data Management Office (BCO-DMO). https://www.bco-dmo.org/ (Accessed September 6, 2017).

ODP/TAMU Science Operator, Ocean Drilling Program: Janus Web Database. http://www-odp.tamu.edu/database/ (Accessed September 6, 2017).

R. D. Müller, M. Sdrolias, C. Gaina, W. R. Roest, Age, spreading rates, and spreading asymmetry of the world's ocean crust. Geochemistry Geophysics Geosystems. 8150 (2008).

Ocean Biological Processing Group, MODIS Aqua Level 3 Global Monthly Mapped 4 km Chlorophyll a v2014.0 (2015).

G. Laske, G. A. Masters, A global digital map of sediment thickness. Eos Trans. AGU 78 (1997).

G. Laske, G. A. Masters, Z. Ma, M. Pasvanos, Update on CRUST1.0 - A 1-degree Global Model of Earth's Crust. Geophysical Research Abstracts, 15 (2013).

R. W. Reynolds, N. A. Rayner, T. M. Smith, D. C. Stokes, W. Wang, An Improved In Situ and Satellite SST Analysis for Climate. Journal of Climate, (2002).

H. D. Schulz, M. Zabel, Marine Geochemistry, H. D. Schulz, M. Zabel, Eds., 2nd Ed. (Springer, 2006).

G. Wang, et al., Quantification of co-occurring reaction rates in deep subseafloor sediments. Geochimica et Cosmochimica Acta 72, 3479-3488 (2008).

J. Kallmeyer, R. Pockalny, R. R. Adhikari, D. C. Smith, S. D'Hondt, Global distribution of microbial abundance and biomass in subseafloor sediment. Proceedings of the National Academy of Sciences U. S. A. 109, 16213-16216 (2012).

J. Sauvage, Sedimentary Catalysis of Radiolytic Hydrogen Production. Open Access Dissertations (2018).

G. Wang, A. J. Spivack, S. D’Hondt, Gibbs energies of reaction and microbial mutualism in anaerobic deep subseafloor sediments of ODP Site 1226. Geochimica et Cosmochimica Acta 74, 3938-3947 (2010).

S. D'Hondt, R. Pockalny, V. M. Fulfer, A. J. Spivack, Subseafloor life and its biogeochemical impacts. Nature Communications 10, 3519 (2019 